\title{
Impact of Text Messaging (SMS) on Hausa speakers' Language Use in Niger and Nigeria
}

\author{
Aboubakar Nana Aichatou*
}

Department of English, Abdou Moumouni University, Niamey, Niger

DOI: $10.36347 /$ sjahss.2020.v08i02.002

| Received: 05.02.2020 | Accepted: 13.02.2020 | Published: 18.02.2020

*Corresponding author: Aboubakar Nana Aichatou

\section{Abstract}

The purpose of the study was not to assess two points of view and to determine which one is accurate. It was to investigate the use of Text Messaging (SMS) and its impact of corruption (abbreviations, acronyms, slang, syntactic reduction, vowel deletion, truncation, orthography, etc.) on Hausa speakers' language use. Over 500 SMS were collected from the researcher and volunteers. Our data unveil such phenomena impacting Hausa native language' use as code switching, code mixing and language transfer which reveal the symbolic value of code choices in the sense it designates how Hausa language is valued in relation to English and French.

Keywords: Text Messaging, Impact, Code-Switching, Code-Mixing, Transfer, Language Ideology, Code Choices. Copyright @ 2020: This is an open-access article distributed under the terms of the Creative Commons Attribution license which permits unrestricted use, distribution, and reproduction in any medium for non-commercial use (NonCommercial, or CC-BY-NC) provided the original author and source are credited.

\section{INTRODUCTION}

Nowadays mobile phone becomes an indispensable and inevitable means of communication throughout the world. It is a necessity. As to the International Communication Union (ITU) there were almost as many mobile cellular subscribers as people in the world [1]. "The device has become de rigueur in people daily lives $[2,3]$. Its use is increasing day by day. Mobile phone has made the world seem smaller. Communication becomes faster and reliable. In modern society, the most important function of mobile phoneis to enable people stay connected. This function is achieved through the interpersonal messaging capabilities. This is, because "the hectic pace of contemporary life makes most people prone to adopting quicker and easier ways of conveying messages. Texting is currently becoming a popular method of communication for both younger and older age groups (...) worldwide (https:// textingandlanguage.wordpress;com/).

What is noticeable is that texting has great impact on language and communication. It is in this context that the present study investigates the impact of text messaging on Hausa speakers' language use in Niger and Nigeria.

Concerning the impact of texting in English language, it causes a great debate among academic, media and educators. Opponents [4], Wood, Plaster and
Bowyer [5] in OSLO [6] support the idea that the effects of texting on language improve literacy (...), with Crystal suggesting that texting has led to more creativity (in EL), giving people opportunities to create their own slang, emoticon, abbreviations, acronyms, etc. whereas proponents $[7-10,8]$ consider text messaging as a threat to language and literacy with O'Connor (2005: page number) stating: "The concern is common that this method of informal writing will lead the bastardization of language."

Still others like Williams [11], Cooper [12] and Lobert-Moris [13] concluded that SMS causes a "detached presence" and a general loss of human connectivity while Ito and Daisuke [14], Yeh [15] and Lim A [16], in their conclusion on youth text messaging practices in Asia, viewed SMS texting as promoting human connectivity; but most to our knowledge there is no such studies relating to Hausa speakers' language use.

The aim of this work was not to assess two points of view: positive/negative and to determine which one is accurate, but to maintain, among others, $M$ Myers-Scotton's [17] stand that the choice of one linguistic variety is symbolic, that code-switching in conversation draws upon language ideological assumptions to index social matters such as ethnic identity, power and prestige, solidarity, distance and social relationships. 
What is the impact (positive/negative) of text messaging on Hausa speakers 'language use in Niger and Nigeria? Does text message usage affect the way Hausa speakers presently use the English and French language and even Hausa language? And if it is so, is it for better or for worse?

The corpus of this investigation comprises texts messages from avariety of sources: male and female, young and adults; students, lecturers, teachers, administrators, etc. from Niger/Nigeria of which a large representative random samples of 500 SMSs was drawn.

\section{Hausa Language}

The Hausa homeland lies astride Niger and Nigeria where Hausa is the most numerically dominant and spoken language. As stated by Dioulde [18] quoting Houis and Bole [19]: "There can be no doubt that there are some African languages spoken by a large number of people. The two numerically largest languages are Kiswahili and Hausa." Next to Arabic even though Swahili has a wider native speaker country spread, Hausa is the most widely spoken language in SubSaharan Africa [20-23]. According to Stride and Ifeka [24], Hausa language is one of the great lingua Franca of Africa and is spoken by many people with little or no Hausa blood; Kraft and Kirk-Greene [25] write: "the Hausa language is generally recognized to be the largest West African language." As a result, all these make Hausa to become like Swahili in East Africa, the lingua franca of the West Africa and thus the sole means of communication in this large area of polyglot Africa [26].

Besides, Hausa is used extensively in local administration in Northern Nigeria though, it has not been fully developed in Niger Republic because of the French policy of assimilation. As a result, the Hausa people had been colonized by two colonial powers: French and English. Both French and English became the official and socially prestigious languages in these countries.

Written in both boko (Latin) and Ajami (Arabic Scripts), Hausa language is today one of the most developed and spoken language in Africa [27]. It was written down very early, probably from the $14^{\text {th }}$ Century and perhaps even before, in Arabic (...) said Alexender [28] quoted by Nana [26].

We note with Shehu Malami [29] quoted by Phillips [20] that "Hausa ability to adopt to new conditions, even to express the most complex of Western ideas, gave it a vast superiority over surrounding African languages, many of which in turn borrow neologism from it." The Hausa speakers like any other language speakers "use communication technologies like mobile phone to "maintain social relationship" [30].

\section{EMPIRICAL REVIEW}

To the best of our knowledge, no empirical research has addressed the impact of text messages on language use among Hausa speakers in the Niger and Nigeria context.

Scholars like Atanda \& Umar [31]; Oluga \& Babalola [32] argue that this form of communication has systematically revolutionized human communication system the world over and has systematically transformed written communication.

Others, following the example of Joan Lee (Date of publication: page number) who said: "The use of text message has changed the way people talk and write giving way to the "decline of quality of written communication", think of texting as ruining and wrecking our language. Lee goes on to state: "those who texted more are less opento new vocabulary whilethose who read traditional media are more opento expanding their vocabulary".

On their part, educationists have observed that text messaging is completely devastating the English language that SMS language has seemingly destroyed the way schoolchildren read, think, and write the conventional English language. O'Connor [9] reports that the more students use tools like instant messaging, the less they are able to separate formal and informal English.

Still some linguists believe that texting deteriorates peoples writing skills, distort their ability to express themselves eloquently through writing and their ability to use words appropriately in contexts.

Nevertheless authors like Crystal [33] raise against this statement the following way:

The drastic and rapid development of technology and the differences it has brought with it are often viewed negatively. Text messaging has been a vital form of communication emerging from the speedy development of technology. Where technology and communication are concerned there is often an air of doubt and distrust.

He continues on: "Ever since the arrival of printing to be the invention of the devil ( ...) people have been arguing that new technology would have disastrous consequences for language" Crystal [4].

Bernard [34], is quoted to report that there are (teachers) who disagree with claims of SMS negativity and view texting simply as a new form of communication 'which is taking hold in the linguistic sphere" and (receive it as) 'new challenges' for teaching and learning but also new opportunities. In fact, proponents consider text messaging as improving literacy and creativity, that texting has made writing 'return to importance'. 
Another, neutral view believes that texting constitutes a different form of language, a sort of modern jargon since each generation has its own jargon.

\section{METHODOLOGY}

For the purpose of studying the impact of text messaging on Hausa speakers' language use a total number of 100 volunteers were selected for the purpose of data collection and each person contributed at least 10 texts messages. So originally, more than 500 texts messages from the researcher and volunteers have been collected and compiled.

\section{FINDINGS AND DISCUSSIONS}

Results of the study revealed that, text messaging impacts Hausa speakers' language use when texting in French and or in English- the use of abbreviations, acronyms, slang, syntactic reduction, deletions of parts of speech, omission of punctuation marks, arbitrary use of these marks, alphanumeric homophony, vowel deletion, initialization and contractions amongst others.For instance:

French:

Ce biendomaj ca alaietrlocaz d dirbjr a la maman, j pensq c ne q partie remise, etes vs rentrMrcibcp BjrmdmeccmenDmn cote Dieu mrcivrmen! vsmavezbcpmankvrmen

\section{English}

By the way I don'trecognise this $\mathrm{n}^{\circ} \mathrm{cn} \mathrm{u}$ enlighten me.

I saw Doe dis night and told him abtur coming. He gave me ur key.

$\mathrm{R} u$ in de room Gud 9te. 9ce drims : How was urnite

Pls expect smthg definite nxt wk. Thnx for ur patience. $\mathrm{U} r$ welcome

These prove Atanda \& Umar [31], Oluga \& Babalola [32] and Joan Lee, O'Connor [9] and other educationists and linguistsright especially if we consider the authors (lecturers/students) of the above messages.

Our findings particularly indicated other most obvious and occurring phenomena of text messaging with concern Hausa speakers' language use in Niger and Nigeria which are code switching, code mixing, and language transfer.

Our findings go in line with the assertion of Deumert and Masinyana [35] we paraphrase as follows: The bilingual writers use two different sets of communicative norms. When writing English and French they employ a range of global non-standard features which allow them to achieve brevity of expression, to optimize speed of communication, and to indicate emotional states; when writing Hausa the maxim of brevity and speed are suspended, (...) and texts close to the standard norm are produced (...). For instance:

\section{Code Switching \\ Hausa/ French}

- Kowayayizagi akasuwa, yasan da wayake!C'est bien toi qui publiquement a rouvert ce débat ! (...)

- Bonjour M. yajiki? Allah yaKorosawki. Bon rétablissement. La CASO doit disparaitre kawai.

- M, yayajiki ? Bonne guérison.

- Assalam, wata Emergency ta taso, inabukatakudi, Zan je kano da gaggawa, Dan Allah samo min deux à Trois Cents mille disi demain seize heures pour pouvoir kitter le Mercredi matin. Merci (..).

- Assalamualaikum NA, da fatankintashilafiya. Juste une pensée positive pour toi. Bonne journée et courage et bonne réussite pour tes recherches

- Kisan da sanninbakiisaba. Reviens sur terre

- AslmHadjia - To barka da asouba da fatankintashicikinkoshinlafiya da fara'a da walwala Si tu peux faire le colis et l'envoyer à Maradi par le bus de 8h 30 STM ou Rimbo à cette adresse (...) j'espère qu'il fait moins frais à Niamey

- Hadjiya, in da hali un peu de carburant. Merci

\section{Hausa/ English}

- Salaam Mundawogidalafiyayauwajen 3.00 am. I thank you for your encouragement when my spirit was low.

- Yes munshigo Dec, yau 12th. Ina ta jiranranan da Zanganki. A yanzuina Benin City for NUC accreditation. Will be back next Friday. Cheers'

- Salaan where are you! TunjiyanakeKiranki a landline ammanakasasamunkijiyakika bar Kandajikoyau da safe! Please get in touch with me even through Whatsapp.

- Salaam. Da fatan kin tashilafiya. Munga certificates dinkiammaba CV. Please send the CV.

\section{Code Mixing}

\section{Hausa/English/French}

- Salaam -BarkadaZuwa, lalemarhaba. Ina da meetingnaSenatea nan sama da offishinVC. In Kin bugozanfito.

- Ka zo gobe da ekivalans na BAC kafinmufarakaratu.

- Salaam. Wannanlambarnayisavingdinta.

- To najiammasaikiyi mini hakourinkarewaniCompilationnarapportda nakeyi

- (..) saijiya da dare naturomikidraftdin tagmail address. Ba ni da data ne a IPA Ddina. 


\section{Language Transfer or Interference}

MacGregor [36] defines language transfer as « the carrying over of grammatical patterns from a person 's L1 to L2 " where (...) according to Lado [37] $\ldots$ individuals tend to transfer the forms and meanings of their native language and culture to the foreign language and culture (...)

- Hum! Tu as le couteau et la viande maintenant !

- Tes souhaits ne vont droit au coeur. Si tu étais auprès de moi je te ferais "le cheval du cou', ma belle.

- Le palu m'a fait tomber

- He throws a quick look at his wife

- It is great time for Agar to give milk to the child;

These phenomena are revealed to be the most occurring, consciously or unconsciously, to Hausa speakers when text messaging. What is noticeable is that when texting that they code switch or code mix or transfer, Hausa speakers "do not observe the fundamental characteristic of sensing: abbreviations, acronyms, omission of vowels, subject pronouns (....)" to maintain Ling and Baron' [38] stand. Contrary, they write words fully, observe the rules of capitalization/punctuation and all the other rules.

Hence, the Hausa are found to code switch, code mix and transfer mainly due to:

- 'Bilingualism or language contact that results "in the lexical borrowing and mixture of English and vernacular expressions" in the speech of West African bilinguals" as stated by Ansre [39]; Bamgbose [40]; Cheng and Butler [41].

- The status [42-46]: Hausa language is today one of the most developed and spoken language in Africa [27] and one of a great linguafranca.

- Modernisation, efficiency as to Kachru [45]; Kamwangamalu [46]; this is because Hausa has "ability to adopt to new conditions, even to express the most complex of Western ideas, (...). Other factors include self-pride, comfortability [42-46] as shown by the population of the current study who feel they should use a national speech and share Malami's [29] view who sees“ (....) European languages $(. .$.$) too offensive in view of their$ colonial overtones.

\section{DISCUSSIONS}

The most notably impact of texts messaging on Hausa speakers' language use are found to be Code Switching/Code Mixing and Transfer. These phenomena, however, have in turn their effects among which are undermining of certain traditional values [45], innovation in the structure of one of the other of the languages code switched or code-mixed [46] and mainly and this is our concern, «making one language to be more dominant than the other, thereby causing the individual to switch always to the dominant language" $[41$.

This claim is partly confirmed by our results as we can see from the examples on pages 8,9 and 10where the switch is to the English and French considered as the dominant languages.

However, the followings show different cliché; things are done the other way round: individualsswitch to the less dominant (Hausavis-a-vis French and English) language.

- Bonjour Ana bien réveillé, to awunilafiya (...).

- Petit quelque chose maialbarka. Allah ya saka da alheri. Salam.

- OK Avant moi pas content avec toi. Yanzu na huce.

- Moustapha, prompt rétablissement ! Allah Koro Sawki.

- Thank you very much for your greetings - I missed the call because I was driving back to KabawafromTinkim. Na bar PG School. In Kin shigocikinmakarantaki min waya.

- Yes UAM has changed a lot but I am sure you can find the VC /Régistra's office. Sauraawaarba'in da takwas in ganki, in Allah yayadda.

- Assalamu Alaikum. Barka da sallah. May Allah accept all our deeds and grant us Aljanna. Allah yamaimaita mana da alkhairi da albarka da lafiya.

Other thing, we can see that the 160 characters limitation does not discourage complex vocabulary use nor prevent the creation of longer and grammatical phrases by Hausa speakers when text messaging.

Why do people feel they should switch to the national language as illustrated by the above instances? We can dare say not only of the imposition of code switching/code mixing as the norms of language use in the most bilingual communities' [46] but also a matter of Self-pride, comfortability, let alone their language's ability to adapt to new conditions, even to express the most complex of Western ideas (modernization/westernization).

Another possible explanation of these findings could be due to symbolic value and ideological matteras asserted by Dubois [47] quoting Myers-Scotton [17] that:

Contrary to the common belief that speakers employ code-switching due to laziness, theirineptitude at producing an utterance in one language, or the needto fill lexical gaps withitems from the other, there is very often a symbolic value in switching to another language. Thus, the choice of one linguistic 
variety is symbolic for a multilingual speech community, as itdesignates the way in which one language is valued in relation to others $(\ldots$ .).

Dubois [47] goes further to state:

Besides themeaning of the utterance, the code choice carries some extra meaning, which is allotted to the language. In other words, language ideologies associated with languages with particular social preferences, provide a context of presuppositions that give code choices significance. Hence, code-switching in conversation draws upon language ideological assumptions to index social matters such as ethnic identity, power and prestige, solidarity, distance and social relationships.

\section{CONCLUSION}

Text messaging usage impacts the way Hausa speakers presently use the English/French language in that they switch tonational language (they code switch, code mix and transfer) and, most intriguing once they do so, they do not observe the maxims of brevity and speed.

Also, this impact proves how Hausa language, a language with particular social preferences is valued in relation to the so-called languages of social prestige, French and English.

In this context, texting has positive impact as it boosts the status of the language being switched/mixed.

The only implication, on the other hand, is that texting may be an impediment to the incipient bilinguals (Hausa speakers) in the sense that these phenomena may properly erode their language use.

\section{REFERENCES}

1. International Communication Union (IUT). The World in 2013: ICT Facts and Figures. 2013.

2. Lenhart A, Ling R, Campbell S, Purcell K. Teens and mobile phones: Text messaging explodes as teens embrace it as the centerpiece of their communication strategies with friends. Pew Internet \& American Life Project. 2010 Apr 20.

3. Ronot X, Benel L, Adolphe M, Mounolou JC. Mitochondrial analysis in living cells: the use of rhodamine 123 and flow cytometry. Biology of the Cell. 1986;57(1):1-7.

4. Crystal, David. 2008 "Texting". ELT Journal: English Language Teachers JournalJanuary.77-83, Academic Search Complete, EBSCOhost (accessed April 8, 2012)

5. Bowyer KW, Hollingsworth K, Flynn PJ. Image understanding for iris biometrics: A survey. Computer vision and image understanding. 2008 May 1;110(2):281-307.
6. Lyche T, Schumaker LL. Mathematical Methods for Curves and Surfaces: Oslo 2000. Vanderbilt University; 2001 Jan 1.

7. Boswell SG, Cole BJ, Sundman EA, Karas V, Fortier LA. Platelet-rich plasma: a milieu of bioactive factors. Arthroscopy: The journal of arthroscopic \& related surgery. 2012 Mar 1;28(3):429-39.

8. Wallace D. Discriminatory mass de-housing and low-weight births: Scales of geography, time, and level. Journal of Urban Health. 2011 Jun 1;88(3):454-68.

9. Connor EE, Mwamuka J, Gole A, Murphy CJ, Wyatt MD. Gold nanoparticles are taken up by human cells but do not cause acute cytotoxicity. Small. 2005 Mar;1(3):325-7.

10. Ophir E, Nass C, Wagner AD. Cognitive control in media multitaskers. Proceedings of the National Academy of Sciences. 2009 Sep 15;106(37):15583-7.

11. Williams R. Culture and society, 1780-1950. Columbia University Press; 1983.

12. Cooper CL, Cooper CP, Dewe PJ, O'Driscoll MP, O'Driscoll MP. Organizational stress: A review and critique of theory, research, and applications. Sage; 2001 Feb 6.

13. Lobert PE, Bourgeois D, Pampin R, Akheyar A, Hagelsieb LM, Flandre D, Remacle J. Immobilization of DNA on CMOS compatible materials. Sensors and Actuators B: Chemical. 2003 Jul 1;92(1-2):90-7.

14. Waki H, Yamauchi T, Kamon J, Ito Y, Uchida S, Kita S, Hara K, Hada Y, Vasseur F, Froguel P, Kimura, S. Impaired multimerization of human adiponectin mutants associated with diabetes molecular structure and multimer formation of adiponectin. Journal of Biological Chemistry, 2003; 278(41), 40352-40363.

15. Yeh JW, Chen SK, Lin SJ, Gan JY, Chin TS, Shun TT, Tsau CH, Chang SY. Nanostructured highentropy alloys with multiple principal elements: novel alloy design concepts and outcomes. Advanced Engineering Materials. 2004 May;6(5):299-303.

16. Kim S, Lim YT, Soltesz EG, De Grand AM, Lee J, Nakayama A, Parker JA, Mihaljevic T, Laurence RG, Dor DM, Cohn LH. Near-infrared fluorescent type II quantum dots for sentinel lymph node mapping. Nature biotechnology. 2004 Jan;22(1):93-7.

17. Myers-Scotton C. Multiple voices. An introduction to bilingualism. Malden, MA: Blackwell Publishers. 2006.

18. Laya D. Mort de la brousse. ENDA; 1979.

19. HouIS M, BOLE R. Intégration des langues dans une politique d'enseignement.1977.

20. Phillips ID. Factors influencing the distribution of growth between stem and axillary buds in decapitated bean plants. Journal of Experimental Botany. 1971 May 1;22(2):465-71. 
21. Zima, P. 1968 Hausa in West Africa: Remarks on Contemporary Role and Functions, In Fishman,J. et al(eds) Language Problems of Developing Nation PP 365-377 New York John Willey and Son.

22. Hiskett, M. 1969. The Occupation of Hausaland with an Introduction of H.F. Backwell. Frank. Cass \&Co. Ltd.

23. White F. The vegetation of Africa: a descriptive memoir to accompany the UNESCO/AETFAT/UNSO vegetation map of Africa by F White. Natural Resources Research Report XX, UNESCO, Paris, France. 1983:187695.

24. Stride GT, Ifake C. "Islam in West Africa Down to 1804" In Peoples and Empires of West Africa. West Africa in History 1000-1800. Nelson. 1971.

25. Kraft CH, Kirk-Greene AH. Hausa: A complete course for beginners. Ibadan: Rombic Concepts Ltd. 1973.

26. Nana AichatouAboubakar, 1996; Sociolinguistic Parameters In Verbal Behaviour (A Case Study Of Hausa In Kano And Zinder) (Unpublished Ph. D Thesis). BUK Kano Nigeria.

27. Galadanci M.K.M \& Salim, B. 1985 "The use of Arabic Alphabet in Formal and Non Formal Education". Commissioned project on behalf of Breda UNESCO

28. Alexander NJ. Vasectomy: long-term effects in the rhesus monkey. Reproduction. 1972 Dec 1;31(3):399-406.

29. Malami CA. Automatic Light Aircraft Readiness Monitor. SAE Technical Paper; 1962 Jan 1.

30. Ling R, Yttri B. Hyper-coordination via mobile phones in Norway, Perpetual contact: mobile communication, private talk, public performance. 2002.

31. Atanda T, Umar MA. An evaluation of global system of mobile communication ( $\mathrm{gsm}$ ) use in news gathering and reporting in kaduna, nigeria. The Nigerian Journal of Communication. 2006;4(1-2):149-72.

32. Oluga SO, Babalola HA. Official Use of English and the Resultant Marginalisation of Indigenous African Languages: The Cases of the Three Major Nigerian Languages. European journal of social sciences. 2012;32(4):619-31.

33. Crystal P, Strano SD, Shcharynski S, Koretz MJ. Using sonography to screen women with mammographically dense breasts. American Journal of Roentgenology. 2003 Jul;181(1):17782.
34. Levin B, Lieberman DA, McFarland B, Smith RA, Brooks D, Andrews KS, Dash C, Giardiello FM, Glick S, Levin TR, Pickhardt P. Screening and surveillance for the early detection of colorectal cancer and adenomatous polyps, 2008: a joint guideline from the American Cancer Society, the US Multi-Society Task Force on Colorectal Cancer, and the American College of Radiology. CA: a cancer journal for clinicians. 2008 May;58(3):130-60.

35. Deumert A, Sibabalwe OM. Mobile Language Choices -- The use of English and isiXhosa in text messages (SMS). Evidence from a Bilingual South African Sample. English, 2008; 2117-347 Worlwide 20,

36. MacGregor WB. Linguistics. An Introduction. London Continuum International Publishing Group. 2009.

37. Lado R. Linguistics Across Cultures. University of Michigan: Ann Arbor. 1957.

38. Ling R, Baron NS. Text messaging and IM: Linguistic comparison of American college data. Journal of language and social psychology. 2007 Sep;26(3):291-8.

39. Ansre G. The influence of English on West African languages. Spency (ed), The English Language in West Africa. Ibadan University Press. 1971.

40. Bamgbose A. The English Language in Nigeria. In: J. Spencer (ed,), The English Language in West Africa. Ibadan: Ibadan University Press. 1971.

41. Cheng L, Butler K. Code-switching: A Natural Phenomenon VS Language "Deficiency". World Englishes, 1989; 8(3).

42. Akere F. A Sociolinguistic Study of a Yoruba Speech CommunityIn Nigeria: Variation and Change in the Ijebu Dialect of Ikorodu, Ph.D. Thesis University of Edinburgh. 1977.

43. Olajoke AS, Abuya EJ. The Manifestation of Code Switching Among 3 Year-Old Yoruba/English Semilinguals. 1989.

44. Hymes, D. 1962. The Ethnography in Speaking. In: T Gladwin (ed,), Anthropology And Man Behaviour. Washington.

45. Kachru Y. Code-mixing, Style Repertoire and Language variation: English in Hindu Poetic Creativity. World Englishes, 1989; 8(3).

46. Kamawangamalu N. Code-Mixing and Modernisation. World English, 1989; 8(3).

47. Dubois I. Language attrition and code-switching among US Americans in Germany Universitat Vechta, Anglistik/Sprachwissenschaft, Driver strass 22, 49364 vechta. 2013. 